\section{HOMERO Y LA EMANCIPACIÓN \\ DE LA JUSTICIA}

HOMER AND THE EMANCIPATION OF JUSTICE

ANTONIO HERMOSA ANDÚJAR ·

Antonio Hermosa Andújar es profesor titular en el área de filosofía de la Universidad de Sevilla.

E-mail: hermosa@us.es

\section{Resumen}

El presente artículo defiende la tesis de que el tratamiento por Homero de la idea de justicia constituye por sí mismo un hito para la civilización occidental. Para ello hubo que emancipar la justicia de las ideas de venganza y subjetividad, que una larga tradición había vinculado con el honor personal del héroe. El efecto inmediato es la consecuente aparición en el reino de la justicia de nuevas prácticas que la desvinculan de la voluntad individual y de nuevos valores que desvinculan dicha voluntad de la violencia. El efecto mediato es el inicio de una nueva concepción de la justicia más igualitaria y social, que a lo largo de un extenso proceso legitimador conducirá hasta su plena institucionalización.

\section{Abstract}

The present article defends the thesis that Homer's treatment of the idea of justice constitutes in itself a milestone for Western civilization. In order to do this, he emancipated justice from the ideas of vengeance and subjectivity which had been traditionally linked to the hero's personal honour. The immediate effect in the realm of justice was the consequent appearance of new practices that set it free from the individual will and of new values which separate that will from violence. The mediate effect was the beginning of a new conception of justice as more egalitarian and social, which over the course of a long, legitimating process would lead to its full institutionalization. 